\title{
A METHOD OF AUTOMATIC DETERMINATION OF THE NUMBER OF THE ELECTRICAL MOTORS SIMULTANEOUSLY WORKING IN GROUP
}

\begin{abstract}
Purpose. Propose a method of automatic determination of the number of operating high voltage electric motors in the group of the same type based on the determination and analysis of the account data of power consumption, obtained from of electric power meters installed at the connection of motors. Results. The algorithm of the automatic determination program for the number of working in the same group of electric motors, which is based on the determination of the motor power minimum value at which it is considered on, was developed. Originality. For the first time a method of automatic determination of the number of working of the same type high-voltage motors group was proposed. Practical value. Obtained results may be used for the introduction of an automated accounting run of each motor, calculating the parameters of the equivalent induction motor or a synchronous motor. References 7, figures 2.
\end{abstract}

Key words: induction and synchronous motors, group of the same type of electric motors, running.

Целью исследований является разработка метода автоматического определения количества работающцх электродвигателей высокого напряжения в группе однотипных на основе определения и анализа учетных данных электропотребления, полученных с приборов учета электроэнергии, установленных на присоединениях электродвигателей. Разработан алгоритм программы автоматического определения количества работающих электродвигателей в группе однотипных. Полученные результаты могут быть использованы для внедрения автоматизированного ведения учета пробега каждого электродвигателя, расчета параметров эквивалентного асинхронного (АД) или синхронного двигателя (СД), которые в свою очередь в дальнейшем могут применяться для оценки эффективности работы группы одинаковых электродвигателей, проведение расчетов статической и динамической устойчивости системы электроснабжения промышленного предприятия, содерэкаей АД или СД. Библ. 7 , рис. 2.

Ключевые слова: асинхронный и синхронный электродвигатели, группа однотипных электродвигателей, пробег.

Introduction. In practice it is impossible to determine the number of network-connected induction (IM) or synchronous (SM) electric motors in a group of one kind without visual control.

Often in electrical equipment to tires $6-10 \mathrm{kV}$ multiple IM are connected, in general, of different type and capacity. In assessing the resulting impact of motors on the short-circuit current at the site of injury it is advisable to replace all the motors or some of their groups by one equivalent IM. For the equivalentation of IM the following parameters are input: the nominal value of the rated power $P_{\text {nom }}$; the relative value of starting current $I_{n}$; multiplicity of starting $m_{n}$ and maximum $m_{\max }$ torques. In the formulas for calculating the equivalent IM they use their number of similar IM $n$ in the group [1]. For example, nominal active power of equivalent IM $P_{\text {nom.ekv }}$ of the group consisting of $n$ motors of rated power of each $P_{\text {nom }}$ is determined by the formula [1]:

$$
P_{\text {nom.ekv. }}=\sum_{j=1}^{n} P_{\text {nom }}
$$

Therefore, to obtain accurate value of equivalent IM parameters we must determine accurately their number. A similar problem is and for groups of SM, too.

The goal of the work is to develop a method for automatically determining the number of working electrical motors of voltage of $6 \mathrm{kV}$ in a group of similar ones based on the definition and analysis of power consumption credential obtained from electricity meters installed on electric connections of motors. The feature of electric motors operation is that the load on their shaft to vary widely. So, when operating multiple IM or SM simultaneously, simple definition of electric power consumption by the group of motors makes it impossible to determine the number of working motors

Analysis of recent investigations and publications. Parameters of equivalent IM or SM (power factor, load factor, maximum and starting torques, parameters of equivalent circuit, etc.) are used to assess the effectiveness of the group of the same IM or SM, calculation of static and dynamic stability of electricity supply systems of industrial enterprises which includes IM or SM, periodic component of the inrush current, to determine residual voltage on tires of power supply during self of IM or SM and other problems. [1]. The theoretical basis of operation modes of IM and SM are developed by Syromiatnikov I.A. in [2]. Problems of stability of a single IM or SM as well as their groups are considered in works by Gurevich I.E. [1]. The tasks of increasing the stability of IM and SM at a temporary loss of power are considered in works by Fishman V.S [3], Tidzhiev M.O. [4], Mikhalev S.V. [5].

Material and results of investigations.

IM or SM can operate in a wide range of power capacity from non-working power to nominal one. Therefore, it is necessary to select a minimum value as a percentage of the nominal power which would be indicative of the on state of each motor. According to [2] the current non-working course of IM $I_{i s}$ is calculated as follows:

$$
I_{i s}=I_{n o m} \cdot\left(\sin \varphi_{\text {nom }}-\frac{\cos \varphi_{\text {nom }}}{b_{\text {nom }}+\sqrt{b_{\text {nom }}^{2}-1}}\right),
$$

where $I_{\text {nom }}$ is the rated current of the electrical motor; $\cos \varphi_{\text {nom }}$ is the rated power factor; $b_{\text {nom }}$ is the ratio of 
maximum torque to nominal one on the IM shaft Calculations carried out by IM catalogue data $\left(\cos \varphi_{\text {nom }}=0.8 \ldots 0.92 ; b_{\text {nom }}=2 \ldots 2.7\right)$ suggest that the minimal value $I_{i s}$ is in the range of $25 \%$ to $40 \%$ of the rated current of the motor. The minimum load on the SM shaft ranges from $35 \%$ to $50 \%$ of the rated current of the motor [2]. These ratios are used to determine the working state of IM or SM.

To determine the number of IM or SM in is proposed to set in relay compartment on each connecting of high-voltage electric motors (Fig. 1) electronic multifunction electricity meters that measure in real-time current, voltage, power, frequency and other parameters of the power consumption mode, and ensure the collection, processing and data transfer in the automated system of control and accounting of electrical energy (ASCAE) in real time.

To the tires of $6 \mathrm{kV}$ of the substation (Fig. 1) three identical high voltages IM are connected. On each IM connection an electronic energy meter is installed. All meters are connected to ASCAE of the enterprise. The values of active power of the electric motor are collected in real time.

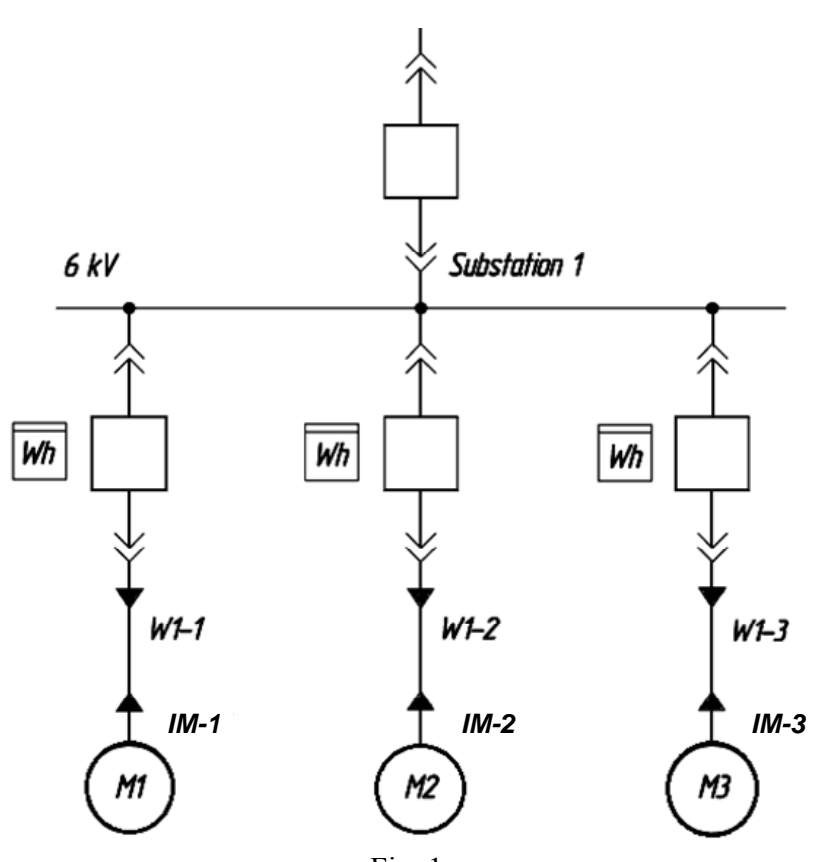

Fig. 1

The measured values after checking for faults are used in specially developed software controlling the IM or SM on state. When the load on each IM or SM more than $25 \%$ of the rated power $P_{\text {nom }}$ of the electric motor, it is deemed to be on.

An algorithm of the software that monitors switched IM or SM is shown in Fig. 2.

The software operates as follows.

The initial data are the number of mounted $m$ and operating $n$ electric motors measured by the meter value of power of the $i$-th motor and its rated power. The counter of the software starts counting from 0 . When the load on the first electric motor exceeds $0.25 P_{\text {ном }}$ of the motor, it is deemed to be on. The same procedure is followed with each next motor. When and $i=m$, then the procedure completes its operation and as output the calculated number of operating electric motors in the group of the same type is obtained.

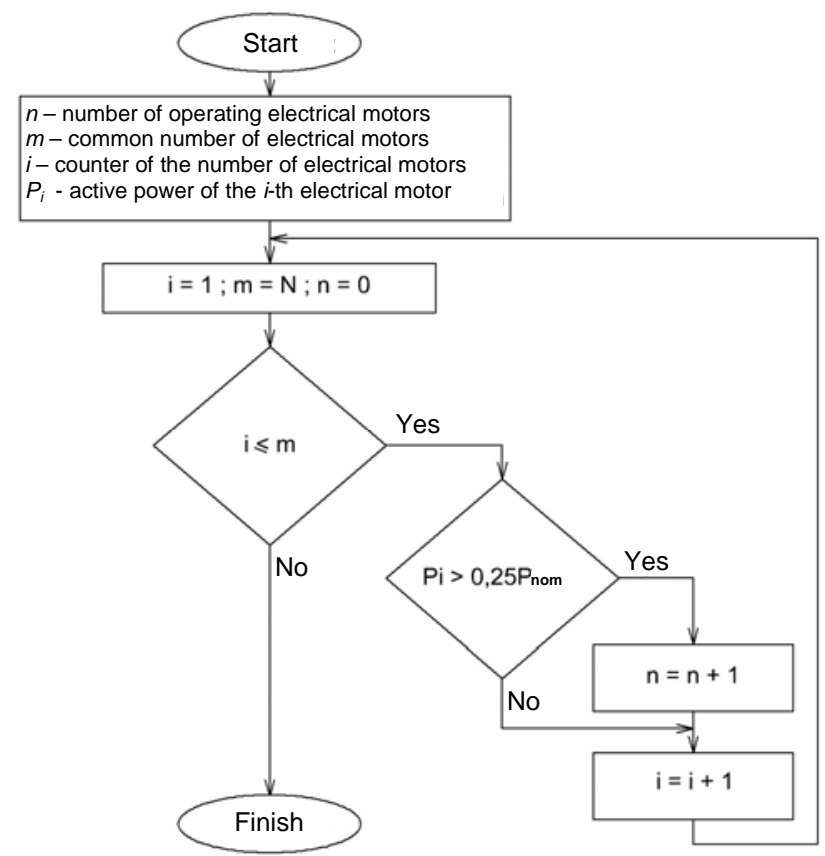

Fig. 2. Algorithm of software controlling the on state of the IM or SM

The analysis showed that knowledge of the number of operated IM and SM be used and for another task of maintenance and repair of electric motors (calculation of each electric motor run, calculate of its overhaul period).

Journal of IM and SM run allows to obtain the exact duration of its operation which guarantees the overhaul period. For timely repair of main electrical equipment it is necessary to fill in an electrical motors run journal at the enterprise. In [6] it is proposed to fill in the run journal electronically but not defined ways of the solution to this problem. Calculation of the number of on motors in realtime makes it possible to solve this problem with minimal cost of labor staff.

To calculate the run of each electric motor it is necessary to know if it operates at the current moment of time or not. So, when in real-time there is information about on state of each IM or SM it is possible to determine the number of hours they operated for any length of time (month, year). By these data turnaround time is calculated. Called turnaround time is interval of equipment operation between next running repair which is measured by the number of hours operated [7].

\section{Conclusions.}

1. A method for determining the number of operated IM or SM in a group of similar electric motors by controlling the load on each motor connection by electricity meters which allows for a wide range of varying load on the motor shaft is developed.

2. The resulting value of the number of operating IM or SM may be used for automated accounting of each motor run, determine the parameters of the equivalent IM or SM which are used for the calculation of static or dynamic stability of electricity supply systems in the industry, evaluating the effectiveness of the group of identical 
motors, periodic component of inrush current, determine the residual voltages on the tires of the power source at self, etc.

\section{REFERENCES}

1. Gurevich I.E., Libova L.E., Khachatrian E.A. Ustoichivost' nagruzki elektricheskikh system [Resistance load of electrical systems]. Moscow, Energoizdat Publ., 1981. 208 p. (Rus).

2. Syromiatnikov I.A. Rezhimy raboty asinkhronnykh $i$ sinkhronnykh dvigatelei [Modes of operation of asynchronous and synchronous motors]. Moscow, Energoatomizdat Publ., 1984. 240 p. (Rus).

3. Fishman V.S. Voltage dips in the grids of industrial enterprises. Minimizing the consequences. Electrical Engineering News, 2004, no.6. Available at: http://www.news.elteh.ru/arh/2004/30/05.php. ． (accessed 18.05.2016). (Rus).

4. Tidzhiev M.O. Improving of the sustainability of continuous production processes during short power failure. Tez. dokl. Vserossiisk. nauk.tekhn. konf. "Elektropotreblenie, energosberezhenie, elektrooborudovanie» [Abstracts of AllRussia Sci.- Techn. Conf. «Power consumption, energy saving, electrical equipment»]. Russia, Orenburg, 2003. pp. 28-29. (Rus).

5. Poliakhov N.D., Mikhalev S.V. Enhancing of the stability of synchronous motors with a short-term power loss. Proceedings of ETU «LETI», 2012. no.10, pp. 62-68. (Rus).

6. Voloshko A.V., Bederak Ya.S. The monitoring system of mode power consumption of the industrial enterprise. Energy: economics, technology, ecology, 2014, no.4, pp. 50-59. (Rus).
7. Sistema tekhnicheskogo obsluzhivaniia $i$ remonta tekhnologicheskogo $i$ teploenergeticheskogo oborudovaniia khimicheskikh predpriiatii Ministerstva promyshlennoi politiki Ukrainy. Utverzhdena Pervym zamestitelem Ministra promyshlennosti Ukrainy A. G. Golubovym 25 aprelia $1996 \mathrm{~g}$. [System of maintenance and repair of heat and power technology equipment on chemical enterprises in the Ministry of Industrial Policy of Ukraine. Approved by the First Deputy of Minister of Industry of Ukraine A.G. Golubov on 25 April 1996]. Kyiv, 1998. 432 p. (Rus).

Received 25.05.2016

A.V. Voloshko ${ }^{1}$, Doctor of Technical Science, Professor,

Ya.S. Bederak', Engineer,

${ }^{1}$ National Technical University of Ukraine «Kyiv Polytechnic Institute»,

37, Prospect Peremohy, Kyiv-56, 03056, Ukraine.

phone +380 47 2392979, e-mail: ei@uch.net

${ }^{2} \mathrm{PJSC}$ «AZOT»,

72, Pervomayskaya Str., Cherkassy, 18014, Ukraine.

How to cite this article:

Voloshko A.V., Bederak Ya.S. A method of automatic determination of the number of the electrical motors simultaneously working in group. Electrical engineering \& electromechanics, 2016, no.5, pp. 61-63. doi: 10.20998/2074-272X.2016.5.10. 